\title{
Immunocompromised Host: from the Early Events until the Impact of Acquired Immunodeficiency Syndrome
}

\author{
Sylvio Celso Gonçalves da Costa
}

\author{
Laboratório de Imunomodulação, Departamento de Protozoologia, Instituto Oswaldo Cruz, Av. Brasil 4365, \\ 21045-900 Rio de Janeiro, RJ, Brasil
}

\begin{abstract}
The concept that microorganisms can modulate the host resistance was historically reviewed in the present article. The importance of African trypanosomiasis in the development of the research on immunosuppression as well as the impact of human immunodeficiency virus infection are discussed. Each day new opportunistic organisms establish a constant challenge for the correct diagnosis of concomitant infections in acquired immunodeficiency syndrome. The importance of parasite infection in the balance of host resistance in the third world was emphasized. Finally, some aspects of Leishmania as opportunistic organisms were presented.
\end{abstract}

Key words: immunocompromised host - acquired immunodeficiency syndrome-Aids - human immunodeficiency virus-HIV

The idea that microorganisms can modulate the host resistance is well known at longtime ago. Chanfort reported in its "maxims" that patients with paludism were partially protected against the pest. And long, long time before the Egyptians had observed empirically that people presenting abscess had become more resistant to epidemic incidents than health ones. In these cases infection promotes immunostimulation but it was also observed that some infections can induce immunosuppression. The notion that infection could induce immunosuppression was brought out chiefly by observations on African trypanosomiasis which induce profound suppression of the host immune system and led to the raise of opportunistic infections. It was observed in the early 20th century that patients suffering of sleeping sickness presented lobar pneumonia (Low \& Castellani 1903). This was later investigated in patients with a generalized immunosuppression after Trypanosoma infection. It has been observed that this suppression can affected programs of vaccination in live-stock carrying out T. vivax and T. congolensis infection. This suppression is correlated with low antibodies to vaccines used in cattle.

In 1981 a report sent to the Centers for Disease Control (CDC) showed that in the past eight months, five cases of pneumonia due Pneumocystis

Fax: +55-21-598.4323

E-mail: sycosta@gene.dbbm.fiocruz.br

Received 7 August 2000

Accepted 4 September 2000 carinii were diagnosed in Los Angeles. Normally this pneumonia was known as an opportunistic disease occurring in patients with cancer or in people treated with immunosupressive drugs. This disease was extremely rare and treated with pentamidine, which was still considered to be an experimental drug. So, only with authorization from the CDC the drug could be distributed. This new fact called the attention of the CDC, since the patients were young homosexual people and in general their immune system was immunocompetent. In parallel, during a period of 30 months, 26 new cases of Kaposi sarcome were detected in young homosexual men in New York and California. Some of these patients also presented pneumonia due to $P$. carinii and other severe opportunistic infections. In January of 1983, new and well documented cases appeared among women maried to men that used injectable drugs, showing that the disease was not exclusive to males. Since the disease was transmited by blood transfusion and sexual contact, the research groups were convinced that acquired immunodeficience syndrome (Aids) was caused by an infectious agent. This hypothesis was confirmed by Luc Montagnier at Pasteur Institut by the isolation of human immunodeficiency virus (HIV) and brought a new impact to the biological and medical science by amplifying the spectra of immunocompromised hosts (Barre-Sinoussi et al. 1983, CDC 1986).

The malnourished host is another condition considered as acquired immune deficiency which exhibits many immunodeficiences similar to those typically observed in Aids. As this occurs in many regions of the third world and in developing countries it contributes to aggravate HIV infection. 
Some of these features include depressed cell mediated immunity (mainly as a consequence of depressed T-cell number), complement deficiencies, reduced phagocytic and microbicidal as well as tumoricida activities of macrophages.

This condition is overlapped by helminthic infections that are common in many regions of developing countries, which is estimated to affect more than 1,5 billion people. People highly infected with helminths in these regions have been proposed to explain a high level of tuberculosis (TB) reactivation (Beyers et al. 1996, Warren et al. 1996). Helminth appears as a potent agent to induce Th2 response which is expressed by high IgE levels. A direct correlation of high serum IgE levels and an incidence of high skin test tuberculin has been observed in some towns of South Africa (Beyers et al. 1998). Similar observation was made in patients suffering with cutaneous leishmaniasis caused by Leishmania braziliensis. In Rio de Janeiro this infection is more benign than those observed in other Brazilian towns. Self cure is admitted by some authors and low dose therapy has been propose with good results (Oliveira Neto et al. 1997). During an out break of cutaneous leishmaniasis in Rio de Janeiro patients presenting large lesions were frequently associated with high total IgE levels (Gonçalves da Costa et al. 1975). Nevertheless specific Leishmania IgE was described in infection by L. braziliensis but not on L. amazonensis (Affchain et al. 1983). It has been observed in Africa that faster progression to Aids occurred in highly endemic areas for helminths (Anzala et al. 1995) was associated with an increased plasma HIV viral load (Dyer et al. 1998). Increased plasma HIV viral load, considered the reliable marker of HIV infected patients (Mellors et al. 1996), is associated with leishmaniasis and decrease following its treatment (Wolday et al. 1999). It has been suggest that pre-treatment HIV viral load influences the response to anti-Leishmania chemotherapy and it was observed that active visceral leishmaniasis is correlated with increased viral replication, supporting the idea that concomitant infections plays an important role in disease progression of either infection (Berthe et al. 1999). In leishmaniasis the discussion is very stimulating since resistance to Leishmania infection is correlated with Th1 response. It has been shown that Th1 cells and particularly IFN$\gamma$ have a protective role in murine $L$. major infection; on the other hand Th2 cells and their products lead to disease progression (Titus et al. 1984, Heinzel et al. 1989). In many situation we can observe a transitory immunedepression as that one caused by the virus of rubella (Lafaix 1990). This virus can exarcebate a concomitant infection by $L$. major (Gonçalves da Costa, unpublished data).
It was shown that $\mathrm{T}$-cell clones of Th1 or Th2 pattern from mice infected by $L$. major reacted with different antigenic fractions (Sadick et al. 1990). However attempts of vaccination have become a difficult task since host immune background in third world is turned to Th2 profile. This may explain little efficacy or lack of protection to TB by BCG vaccination in Africa and Asia prophylactic programs. HIV/Aids brings out the protozoan $L$. donovani and other species of Leishmania as opportunistic parasite. HIV, Leishmania sp. and Mycobacterium for example, which are parasite of immune cells present many common aspects chiefly characterized by the suppression of the host immune response, being the inducement of the Th1 suppression one of the most important mechanisms.

The cure and lesion healing lead to a premunition condition, since it is possible to isolate the parasite from scar ten years after healing (Oliveira Neto et al. 1997). HIV infection can reactivate either visceral (Badaró et al. 1986, Cortés et al. 1997) or cutaneous leishmaniasis (Machado et al. 1992). When Leishmania is analyzed as an opportunistic organism it presents many aspects to be considered; one of the most important is the dissemination of the infection. Co-infection with HIV lead to atypical forms of clinical presentation (Gradoni \& Gramiccia 1994, Michiels et al. 1994). The association of different pathologies may occur as leishmaniasis, Kaposi's sarcoma and Aids. It is interesting to emphasize that increased plasma HIV viral load has been observed in association with leishmaniasis and decreasing levels were observed after Leishmania treatment (Wolday et al. 1999).

Thus different mechanisms seem to favor HIV viral load in immunocompromised host: (a) inhibition of Th1 response by the induction of Th2 by helminths prior to HIV infection; (b) competition on the same Th pattern seems to be important for host resistance against HIV and other microorganisms during concomitant infection.

Opportunistic parasitoses have been diagnosed more and more often in most developing countries and polyparasitisme become a field very attractive. Some opportunistic organisms as Microsporidia have been underestimated (Schottelius \& Gonçalves da Costa 2000) and prevalence of this and other opportunistic microorganisms or parasites tends raised since accurate diagnostic methods will be applicated.

Another point to be emphasize is that in children, disease outcome is usually faster and more serious than in adults, and high mortality rate due to serious opportunistic infections (Bernstein et al. 1989, Ortigão-de-Sampaio et al. 1999) in children in general is more affected by helminths. Polyparasitism can also interferes with immuno- 
diagnostic tests either directly through cross-reactions or indirectly through its effect on immune system (Buck et al. 1978).

The prevalence of opportunistic parasitic infections has particularities in function of endemic problems of each region. Cryptosporidium and Isospora belli appear between the most frequent opportunistic parasitic infections in African patients with Aids (Henry et al. 1986, Pape et al. 1989, Datry 1989, Colebunders et al. 1998). The present workshop will show besides the general aspects of immunocompromised host, the situation of opportunistic parasitoses and mycoses in Brazil. Chagas disease appears in Latin America as an important opportunistic organism and presents frequent infection of central nervous system (Rocha et al. 1994). Reactivation of Chagas disease in immunocompromised patients outside Aids has been described either cancer or in organ transplantation (Mattosinho-França et al. 1969, Monteverde et al. 1976, Jost et al. 1977, Kodl et al. 1982, Rocha et al. 1994). The action of immunosuppressive drugs in American trypanosomiasis has been investigated in experimental model and many aspects has been correlated with the pathology observed in immunocompromised patients in which Chagas disease reactivation occur (Gonçalves da Costa \& Calabrese et al. 1992, Calabrese et al. 1996, 2000, Calabrese 1999). It has been suggest that eradication of helminthic infections may have an important impact on Aids as well TB in developing countries (Bentwich et al. 1999) which will be a good program of investigation in our country. It was also emphasize many aspects of opportunistic mycobacterium species and host defense mechanisms.

\section{REFERENCES}

Afchain D, Desjeux P, La Fuente C, Le Ray D, Cesbron JY, Neyrink JC, Capron A 1983. Specific IgE antibodies to Leishmania braziliensis in patients with mucocutaneous leishmaniasis. Ann Immunol (Paris) 134C: 311-319.

Anzala AO, Nagelkerke NJD, Bwayo JJ, Holton D, Moses S, Ngugi EN, Ndinya-Achola JO, Plummer FA 1995. Rapid progression to disease in African sex workers with human immunodeficiency virus type 1 infection. J Inf Dis 171: 686-689.

Badaró R, Carvalho EM, Rocha H, Queiroz AC, Jones TC 1986. Leishmania donovani: an opportunistic microbe associated with progressive disease in three immunocompromised patients. The Lancet 22: 647649.

Barre-Sinoussi F, Chermann JC, Rey F, Nugeyre MT, Chamaret S, Gr Dauguet C, Axler-Blin C, VezinetBrun F, Rouzioux C, Rozenbaum W, Montagnier L 1983. Isolation of a T-lymphocyte retrovirus from a patient at risk for acquired immune deficiency sindrome (AIDS). Science 220(4599): 868-871.
Bentwich Z, Kalinkovich A, Weisman Z, Borkow G, Beyers N, Beyers AD 1999. Can eradication of helminthic infections change the face of AIDS and tuberculosis? Immunol Today 20: 485487.

Bernstein CJ, Bye MR, Rubinstein A 1989. Prognostic factors and immunodeficiency syndrome and Pneumocystic carinii pneumonia. Am J Dis Child 143: 775-778.

Berthe N, Wolday D, Hailu A, Abraham Y, Ali A, GebreMichael T, De P, Sonnerborg A, Akuffo H, Britton $S$ 1999. HIV viral load and response to antileishmanial chemotherapy infected patients. AIDS 13: 1921-1925.

Beyers AD, Van Rise A, Adam J, Fenhalls G, Gie RP, Beyers N 1998. Novartis Foundation, Symposium 217: 145-157.

Beyers N, Gie RP, Zietsman HL, Kunneke M, Tatley M, DPR 1996. The use of a geographical information system (GIS) to evaluate distribution of tuberculosis in a high-incidence community. S Afr Med J 86: 40-44.

Buck AA, Anderson RI, Mac Rae AA 1978. Epidemiology of polyparasitism. III Effects on the diagnostic capacity of immunological tests. Tropen Med Parasit 29: $145-155$.

Calabrese K, Lagrange PH, Gonçalves da Costa SC 1996. Chagas' disease: enhancement of systemic inflammatory reaction in cyclophosphamide treated mice. Int J Immunopathol 18: 505-514.

Calabrese KS 1999. Immunosuppressive drugs as a tool to explore the immunopathology in experimental Chagas' disease. Mem Inst Oswaldo Cruz 94 (Suppl. I): 273-276.

Calabrese KS, Paradela ASRC, Zaverucha do Valle T, Tedesco RC, Silva S, Mortara RA, Gonçalves da Costa SC 2000. Study of acute chagasic mice under immunosuppressive therapy by cyclosporin A: modulation and confocal analysis of inflammatory reaction. Immunophology 47: 1-11.

Centers for Disease Control update 1986. Acquired immunodeficiency syndrome United States. MMWR 35: 17-21.

Colebunders R, Lusakumuni K, Nelson AM, Gigase P, Lebughe I, Van Marck E, Kapita B, Francis H, Salaun JJ, Quinn TC 1998. Persistent diarrhoea in Zairian AIDS patients: an endoscopia and histological study. Gut 29: 1687-1691.

Cortés P, Cardeñosa N, Romani J, Gállego M, Muñoz C, Barrio JL, Riera C, Portú M 1997. Oral leishmaniasis in an HIV-positive patient. Trans $R$ Soc Trop Med Hyg 91: 438-439.

Datry A 1989. Diagnostic des parasitoses et mycoses, SIDA, Infection à VIH, aspects en Zone Tropicale. UREJ: 218-223.

Dyer JR, Kazembe P, Vernazza PL, Gilliam BL, Maida M, Zimba D, Hoffman IF, Royce RA, Schock JL, Fiscus SA, Cohen MS, Eron Jr JJ 1998. High levels of human immunodeficiency virus type 1 in blood and semen of seropositive men in sub-Saharan Africa. J Inf Dis 177: 1742-1746.

Gonçalves da Costa SC, Calabrese KS 1992. Schizotrypamids: the occurrence of dermatitis in 
immunodeficient animals infected with Trypanossoma cruzi. Mem Inst Oswaldo Cruz 87 (Suppl. I): 81 .

Gonçalves da Costa SC, Kanitz M, Povoa H 1975. IgE in sera of patients with American custaneous leishmaniasis. J Protozool 22: 35A.

Gradoni L, Gramiccia M 1994. Leishmania infantum tropism: strain genotype or host immune status? Parasitol Today 10: 264-267.

Heinzel FP, Sadick MD, Holaday BJ, Coffman RC, Lucksley RM 1989. Reciprocal expression of interferon- $\gamma$ on interleukin 4 during the resolution or progression of murine leishmaniasis. J Exp Med 159: 59-72.

Henry MC, De Clercq D, Lokombe B, Kayembe K, Kapita B, Mamba Mbendi N, Mazebo P 1986. Parasitological observations of chronic diarrhoea in suspected AIDS adult patients in Kinshasa (Zaire). Trans $R$ Soc Trop Med Hyg 80: 309-310.

Jost L, Turin M, Etchegoyen P, Leiguarda R, Taratutu AC, Iotti R 1977. Meningoencefalite chagasica em paciente com tratamiento imunosupresor por transplante renal. Rev. Neurol Agent 3: 425-428.

Kodl S, Pichering LK, Frankel, LS, Yaeger RG 1982. Reactivation of Chagas' disease during therapy of acute lymphocytic leukemia. Cancer 50: 827-828.

Lafaix C 1990. La rougeole: un modèle d'immunodépression acquise. Med Sciences (special number): 12-18.

Low GC, Castellani A 1903. Report of the Sleeping Sickness Commission. Proc R Soc London 2: 14.

Machado ES, Braga ML, Da Cruz AM, Coutinho SG, Vieira AR, Rutowitsch MS, Cuzzi-Maya T, Grimaldi Jr G, Menezes JA 1992. Disseminated American muco-cutaneous leishmaniasis caused by $L$. braziliensis in patient with AIDS: a case report. $\mathrm{Mem}$ Inst Oswaldo Cruz 87: 487-492.

Mattosinho-França LC, Lemos S, Fleury RN, Melarajmo FR, Ramos Jr A, Pasternak J 1969. Molestia de Chagas crônica associada à leucemia linfática. Ocorrência de encephalite aguda com alteração do estado immunitário. Arq Neuropsiquiatr 27: 59-66.

Mellors JW, Rinaldo Jr CR, Gupta P, White RM, Todd JA, Kingsley LA 1996. Prognosis in HIV-1 infection predicted by the quantity of virus in plasma. Science 272: 1167-1170.
Michiels JF, Monteil RA, Hofman P, Perrin C, Fuzibet JG, Lefichoux Y, Loubière R 1994. Oral leishmaniasis and Kaposi's sarcoma in an AIDS patient. $J$ Oral Path Med 23: 45-46.

Monteverde DA, Taratuto AC, Lucatelli N 1976. Meningoencefalite chagásica aguda em pacientes imunossuprimidos. Rev Neurol Argent 22: 260-266.

Oliveira Neto MP, Schubach A, Mattos SC, Golçalves Costa, C Pirmez 1997. A low-dose antimony treatment in 159 patients with American cutaneous leishmaniasis: extensive follow up studies (up to 10 years). Am J Trop Med Hyg 57: 651-655.

Ortigão de Sampaio MB, Abreu TF, Linhares CMI, Ponce LA, Castelo Branco LRR 1999. Surrogate markers of disease progression in HIV infected children in Rio de Janeiro, Brazil. J Trop Pediatrics 45: 299-302.

Pape WJ, Verdier RI, Johnson Jr WD 1989. Treatment and prophylaxis of Isospora belli infection in patients with the acquired immunodeficiency Syndrome. N Engl J Med: 1044-1047.

Rocha A, Meneses CA, da Silva AM, Ferreira MS, Nishioka SA, Burgarelli MK, Almeida E, Turcato Júnior G, Metze K, Lopes ER 1994. Pathology of patient with Chagas' disease and acquired immunodeficience syndrome. Am J Trop Med Hyg 50: 261-268.

Sadick MD, Lucksley RM, Tubbs C, Raff HV 1990. Murine cutaneous leishmaniasis: resistance correlates with the capacity to generate interferon- $\gamma$ in response to Leishmania antigens in vitro. J Immunol 136: 655-660.

Schottelius J, Gonçalves da Costa SC 2000. Microsporidia and Acquired Immunodeficiency Syndrome. Mem Inst Oswaldo Cruz 95 (Suppl. I): 133-139.

Titus RG, Kelso A, Louis JA 1984. Intracellular destruction of Leishmania tropica by macrophages activated with macrophage activating factor/interferon. Clin Exp Immunol 55: 157.

Warren R, Hauman J, Beyers N, Richardson M, Schaaf HS, Donald P, Helden P 1996. Unexpectedly high strain diversity of Mycobacterium tuberculosis in a high-incidence community. S Afr Med J 86: 45-49.

Wolday D, Berhe N, Akuffo H, Britton S 1999. Leishmania-HIV infection: immunopathogenic mechanism. Parasitol Today 15: 182-187. 